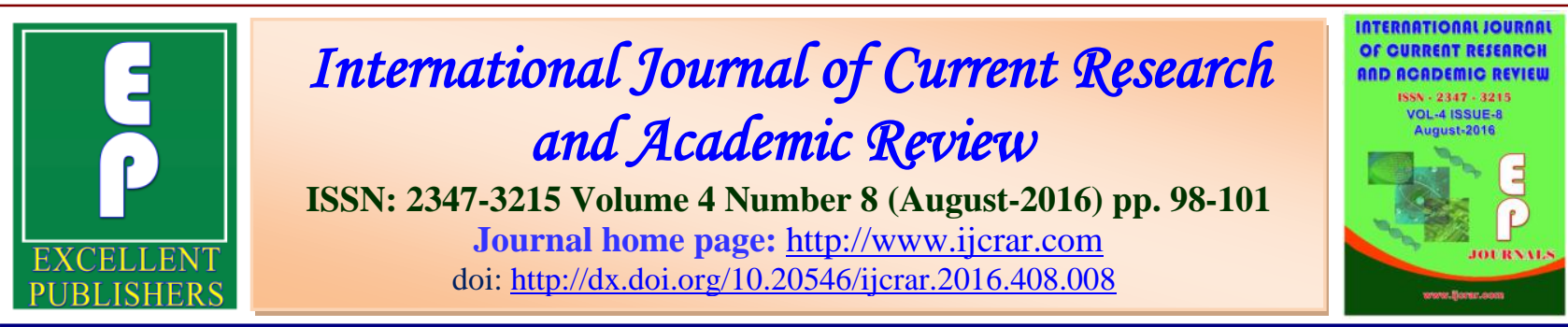

\title{
A Comparative Study of Online and Campus Recruitment Methods in selected software companies in Chennai, India
}

\author{
TI. M. Swaaminathan* and P. Balaji \\ PG and Research Department of Commerce, Pachaiyappa's College for Men, Kanchipuram, \\ India
}

\section{*Corresponding author}

\begin{tabular}{l|l}
\multirow{2}{*}{$\begin{array}{l}\text { KEYWORDS } \\
\text { Recruitment Methods, }\end{array}$} & A B S T R A C T \\
\cline { 2 - 3 } Software Companies. & $\begin{array}{l}\text { Online recruitment has developed into a cost and time efficient proposition } \\
\text { for the HR departments for searching and hiring potential talents. Despite its } \\
\text { advantages, Online-recruitment has so far failed to generate appreciable } \\
\text { response from job-seekers across the world due to perceptions about lack of } \\
\text { credibility of the medium over traditional media such as newspaper } \\
\text { advertisements and employment. Studies have also shown that poor design of } \\
\text { online recruitment websites can have negative impression on job seeker's } \\
\text { attitude towards the portals and may lead to their reluctance to apply for the } \\
\text { jobs posted in such websites. }\end{array}$
\end{tabular}

\section{Introduction}

The human resources are the most important assets of an organization. The success or failure of an organization is largely dependent on the caliber of the people working there in. Without positive and creative contributions from people, organizations cannot progress and prosper. In order to achieve the goals or the activities of an organization, therefore, they need to recruit people with requisite skills, qualifications and experience. While doing so, they have to keep the present as well as the future requirements of the organization in mind.

Recruitment is distinct from Employment and Selection. Once the required number and kind of human resources are determined, the management has to find the places where the required human resources are/will be available and also find the means of attracting them towards the organization before selecting suitable candidates for jobs. All this process is generally known as recruitment. Some people use the term "Recruitment" for employment. These two are not one and the same. Recruitment is only one of the steps in the entire employment process. Some others use the term recruitment for selection.

\section{Online Recruitment}

Online recruitment uses the power of the internet to match people to jobs. 
Fundamentally, it is about advertising vacancies on either job sites or corporate websites. At this very basic level it is particularly effective at getting a high level of response. While it may generate hundreds more applications than traditional print advertising, simply attracting more candidates is only part of the jobs. The current view is that truly effective online recruitment could be as low as $10 \%$ of the top blue chip corporate companies

What are the benefits of online recruitment?

- Wide geographical reach

- Speed

- Low cost

- Automating the process

- Interaction with candidates

\section{Campus Recruitment}

It is a method of recruiting by visiting and participating in college campuses and their placement centers. Here the recruiters visit reputed educational institutions such as IITs, IIMs, colleges and universities with a view to pick up job aspirants having requisite technical or professional skills. Job seekers are provided information about the jobs and the recruiters, in turn, get a snapshot of job seekers through constant interchange of information with respective institutions.

A preliminary screening is done within the campus and the short listed students are then subjected to the remainder of the selection process.

If campus recruitment is used, steps should be taken by human resource department to ensure that recruiters are knowledgeable concerning the jobs that are to be filled and the organizations and understand and employ effective interviewing skills.

\section{Guidelines for campus recruiting}

Companies using college campuses as recruitment source should consider the following guidelines:

Identify the potential candidates early: The earlier that candidate with top potential can be identified, the more likely the organization will be in a position to attract them.

Employ various means to attract candidates: These may include providing research grants; consulting opportunities to faculty members, funding university infrastructural requirements, internships to students, etc. in the long run these will enhance the prestige of the company in the eyes of potential job seekers.

Offer training to campus interviews: Its better to devote more time and resources to train on campus interviewers to answer specific job -related questions of applicants.

Come out with a competitive offer: Keep the key job attributes that influence the decisions of applicants such as promotional avenues, challenging assignments, long term income potential, etc., while talking to candidate

\section{Advantage of Online Recruitment}

Online Recruitment allows for immediate real-time interaction and $24 \times 7$ hiring/job search activity. Employers can post a job in as little as 20 minutes on a career site such as Bayt.com with no limits to ad size and start receiving CVs in response immediately. The posting typically remains active for as long as 30 days and continues to receive applicant CVs immediately as job seekers come across it. This is in comparison to traditional methods where a newspaper ad may take appear a week later and only for a 
day, or a recruiter has to wait till month-end to reap the benefits of an ad in a monthly industry or geography-specific publication. Typically, online recruitments hiring is on average $70 \%$ faster than traditional hiring methods and the recruiting cycle is speeded up at every stage from posting, to receiving $\mathrm{CVs}$ to filtering to managing the contacts and workflow

The main objectives of this study includes, the organizations would be influenced by many elements that encourage the transition face from campus recruitment process to online recruitment process. And to identify new ways of improving the present recruitment procedure. Also to highlight the benefits of online recruitment.

\section{Research Methodology}

\section{Area of study}

This is done with the primary objective of ascertaining the recruitment and selection process in IT sector.

\section{Sampling}

The sample includes all the HR recruiters of different organizations of IT companies.

The respondents are basically HR recruiters for whom a questionnaire has been prepared.

Sample size is 100 the sampling technique that has been used is simple and random basis.

Cross Tabulation of association between Age and the reason for taking up a job at IT SECTORS

$\mathbf{H}_{\mathbf{0}}$ : There is no association between age and the reason for taking up a job at IT sectors

$\mathbf{H}_{1}$ : There is association between age and the reason for taking up a job at IT sectors

\begin{tabular}{|l|c|c|c|c|c|c|c|}
\hline \multirow{2}{*}{ Age } & \multicolumn{6}{|c|}{ Reason for taking up a job at IT Sectors } & \multirow{2}{*}{ Total } \\
\cline { 2 - 7 } & $\begin{array}{c}\text { Pay } \\
\text { benefits }\end{array}$ & Designation & $\begin{array}{c}\text { Brand } \\
\text { Image }\end{array}$ & $\begin{array}{c}\text { Career } \\
\text { Development }\end{array}$ & $\begin{array}{c}\text { Job } \\
\text { profile }\end{array}$ & Others & \\
\hline $18-28$ & 4 & 4 & 2 & 41 & 6 & 5 & 62 \\
$29-38$ & 3 & 1 & 0 & 25 & 8 & 0 & 37 \\
\hline $39-48$ & 0 & 0 & 1 & 0 & 0 & 0 & 1 \\
\hline Total & 7 & 5 & 3 & 66 & 14 & 5 & 100 \\
\hline
\end{tabular}

\section{Inference}

It is found from the above table that the alternative hypothesis $\mathrm{H}_{1}$ is accepted since the significance value is less than 0.05 . This means that the employee's reasons for taking up a job of IT sectors vary with their age. Younger employees look out for a good reference for the future career and higher compensation whereas older employees prefer more promotions and reduced working hours. 
Cross Tabulation of association

Relationship between Gender and through what source are you recruited

$\mathbf{H}_{\mathbf{0}}$ :there is no relationship between gender and through what source are you recruited.
$\mathbf{H}_{\mathbf{1}}$ - there is relationship between gender and through what source are you recruited

\begin{tabular}{|l|l|l|l|l|l|l|}
\hline Gender & Consultant & Job Portals & $\begin{array}{l}\text { Campus } \\
\text { Interview }\end{array}$ & $\begin{array}{l}\text { Casual } \\
\text { Application }\end{array}$ & Others & total \\
\hline Male & 12 & 8 & 6 & 18 & 3 & $\mathbf{5 8}$ \\
\hline Female & 7 & 8 & 3 & 23 & 7 & $\mathbf{4 2}$ \\
\hline Total & $\mathbf{1 9}$ & $\mathbf{2 1}$ & $\mathbf{9}$ & $\mathbf{4 1}$ & $\mathbf{1 0}$ & $\mathbf{1 0 0}$ \\
\hline
\end{tabular}

\section{Inference}

For the Chi square value11.603 with degree of freedom 4 the significance value is.021 which is less than. 05 . So we may reject the null hypothesis and accept the alternate hypothesis. It means that there is a significant association between gender and the source of recruitment.

\section{Conclusion}

The ideal recruitment effort will attract a large number of qualified applicants who will take the job if it is offered. It should also provide information so that unqualified applicants can self selected themselves out of the job candidacy, i.e. a good recruiting program should attract the qualified and not unqualified candidates. If the right person is selected, he is valuable asset to the organization and if faulty selection is made the employee will become a liability to the organization. Therefore, it deserves great care and concern to formulate and implement recruitment strategies and sourcing process, with a foresight towards higher organizational achievement. The sole purpose of the project was to study the sourcing process vis-à-vis to entry level openings and to recommend changes in current process to make sourcing more cost effectiveness.

\section{References}

Kothari, C.R. "Research Methodology", Methods and Techniques, Wishma Prakashan, New Delhi.

http://www.minfosystems. com/ erecruitment-solution india/ recruitement-softwareindia.html

http://www.123oye.com/jobarticles/business-corporates/erecruitment.htmment:

http://suite101.com/article/online-erecruting-benefits-and-challengesa348215

http://www.cvmail.net/talentmanagement/erecruitment-challenge/

\section{How to cite this article:}

Swaaminathan, TI. M., and Balaji, P. 2016. A Comparative Study of Online and Campus Recruitment Methods in selected software companies in Chennai, India. Int.J.Curr.Res.Aca.Rev.4(8):98-101. doi: http://dx.doi.org/10.20546/ijcrar.2016.408.008 